Vol. 2, No. 2, December 2021

DOI: https://doi.org/10.18196/ijiep.v2i2.12324

\title{
Relationship Between Students' Learning Outcomes in WAEC and NECO Arabic Language Examinations in North-Central Nigeria
}

\author{
Musa Siddiq Abdullahi*, Abdul Ganiy Abdus Salaam Oladosu \\ Department of Arts Education, Faculty of Education, University of Ilorin, Nigeria \\ *Corresponding email: abdullahi.ma@unilorin.edu.ng
}

\section{ARTICLE INFO}

Article History

Received : 15/07/2021

Revised : 22/09/2021

$05 / 10 / 2021$

Accepted: 07/10/2021

Keywords:

Relationship, Learning

Outcome, WAEC and

NECO, Arabic Language, Examination, North-

Central

\begin{abstract}
Despite the fact that the certificates being awarded by senior school WAEC and NECO are said to be comparable, yet, stakeholders in the education sector doubt their correspondence in terms of students' learning outcomes. While some students only register for NECO believing that they could not pass WAEC. This was part of what necessitated this study by determining the correspondence between students' learning outcomes in senior school WAEC and NECO Arabic Language examinations in North-central from 2015 to 2019 academic sessions. This study was a descriptive study of the correlational type. Only the results of candidates that sat for WAEC and NECO Arabic Language examinations were logically selected for this study via a researcher-designed proforma. Thus, 948 students constituted the sample size for this study using a multistage sampling procedure. Data collected were analyzed using the percentage to answer the research questions while the Pearson's chi-square at 0.05 alpha level was used to test the hypotheses. Findings indicated that a significant association existed between students' learning outcomes in WAEC and NECO Arabic examinations in North-central Nigeria. It was therefore recommended that teachers of Arabic should work harder to sustain their students' performance in Arabic Language.
\end{abstract}

This is an open-access article under the CC BY-SA license.

\section{Citation:}

Abdullahi, M. S. \& Oladosu, A. G. A. S. (2021). Relationship between students' learning outcomes in WAEC and NECO Arabic language examinations in North-Central Nigeria. International Journal of Islamic Educational Psychology, 2(2), 127-141. DOI: https://doi.org/10.18196/ijiep.v2i2.12324 
Abdullahi \& Oladosu | Relationship Between Students' Learning Outcomes in WAEC and NECO Arabic Language Examinations in North-Central Nigeria

\section{INTRODUCTION}

Language learning could not be inevitably separated from the factor of personal learning. Indeed, it becomes salient indicator of the success of foreign language learning. Inherent personality attached in each individual can be constructed and thus could assist the learning process. Moreover, the constructed personality in each individual, becomes a basis of Arabic learning (Hamidin, 2015). Through this such subjective perspective, the development of language proficiency can be established due to distinct personalities in each individual distinguishing one from the others. Starting from cultural conflict, it will become an initial issue once it is not accelerated greatly. Certainly, not all Arab matters are Islam since Islam does not merely necessarily reflect Arab. Thus, through the contextual understanding of culture, it eases students in learning the language. They will never thoroughly master a language if they do not understand the cultural context of the language. Despite the preliminary step, it at least helps them to use the language properly based on its daily use (Wekke et al., 2016).

Motivation is considered key to success through which it enlivens learning interest despite varied barriers or obstacles faced. Once motivation is mainly taught in initial phase, there will be no obstacle that could stop the learning process (Yusuf \& Wekke, 2015). In fact, even students face any obstacles, they would patiently bear them in order to maintain their learning interest. Therefore, giving stimuli to enhance students' learning motivation is as important as the learning materials per se which ultimately guides them to undergo the learning process (Ahmad, 2009).

In another context, a learning process without any optimism tends to yield nonoptimal outcomes. Through optimism, their effort will be sustained and constantly strive to achieve the best outcomes. Repeatedly ongoing activities in defined long period of time will create positive enforcement. Once it stops, however, it will decrease students' ability. Thus, it necessarily needs repetition to develop desired behaviors in order to achieve great learning achievement. In other words, learning achievement emerges as the achieved abilities or competencies (Wekke, 2015).

Education has been seen as a veritable source through which an individual could be adequately equipped to realize his/her full potentials in life (Khaidir \& Suud, 2020). As a process of human learning and one of the instruments for rapid economic, sociocultural, political, technological, and scientific development, education has been the greatest legacy that every nation bequeaths its citizenry. No wonder Nigeria continually dispenses greater part of its yearly income on educational sector. This is evident in the growing number of pre-school, primary, secondary and tertiary institutions of learning in Nigeria. Meanwhile, secondary education being the bedrock for higher education occupies a strategic place in the Nigerian educational system (Ogunbanwo, 2014). Among the several subjects taught and learned in Nigerian secondary schools is Arabic studies (which is 
Abdullahi \& Oladosu | Relationship Between Students' Learning Outcomes in WAEC and NECO Arabic Language Examinations in North-Central Nigeria

optional) for all Muslim students registering for the Senior School Certificate Examinations (Abdullahi, 2020).

Arabic education as a subject of learning in many Nigerian schools is the study of the language of Arabs which belongs to the Semitic group of languages. Arabic is the second largest most widely used alphabetic writing system in the world (while the Latin alphabet is the most widespread). The Arabic script has been adapted to such diverse languages as Persian, Turkish, Spanish and Swahili (Adeyemi, 2016). In Africa, it is spoken as a native language in Algeria, Comoro Islands, Djibouti, Egypt, Eritrea, Libya, Mauritania, Morocco, Somalia, Sudan, and Tunisia. In the Middle East, Arabic is spoken as a mother tongue in countries such as Bahrain, Iraq, Jordan, Kuwait, Lebanon, Oman, Palestine, Qatar, Saudi Arabia, Syria, United Arab Emirates, and Yemen (Oseni, 2004). Today, Arabic is a universally recognized language occupying a position, which is not less in status and rank than such International Languages as English, French, or Germany (Onisabi, Adamu \& Jami'u, 2007).

Arabic is not a strange language to Nigeria. Indeed, its status is somewhat fluid in this regard. It is spoken as a 1st language (L1) by the Shuwa Arabs of Bornu State; as a $2^{\text {nd }}$ language (L2) by some Nigerian Muslims, who studied Arabic instead of the English language after they had acquired their respective Nigerian languages; and as a Foreign Language (FL) by Nigerians who studied Arabic for their academic or professional careers (Oladosu, 2003). Arabic was the medium of external contact, state correspondence, and historical documentation during the Islamically-oriented Empire of Kanem/Bornu, while the pre-colonial Hausa States of the northern part of Nigeria had their history documented not in any other languages than Arabic (Abdullahi, 2020). The Arabic Language is thus a vital means of communication and interaction in Nigeria, particularly among Muslims.

Therefore, Arabic teaching and learning has a long history in Nigeria even before the advent of the British colonization and has contributed immensely to the development of civilization and education in the world (Sirajudeen, 2003). Onisabi, Adamu, and Jami'u (2007) asserted that many great Muslims have written many works in Arabic on various disciplines such as Philosophy, History, Mathematics, Chemistry, Physics, Natural Sciences, Medicine, Mysticism, Theology and a lot of others. The great Muslim scholars who wrote these works included Jabir Ibn Hayyan (Akyol, 2018), the father of Chemistry; AlRazi, Alchemist, Philosopher, and natural scientist, Ibn Khaldun, an historian; and Usman Ibn Fodio, Philosopher, Mystic and Reformer. The works of these great men were translated into English and other languages and researched upon (Onisabi, Adamu \& Jami'u, 2007). No wonder its curriculum was introduced to secondary education and an independent course of study at the higher institution of learning in Nigeria today. 
Given the historical, political, diplomatic, cultural and educational relevance of Arabic learning in Nigeria, many Arabic institutions have been located in places such as Sokoto, Gwandu, Kano, Ilorin, Ibadan, and Lagos. After the independence and in attempt to modernise Arabic learning, some notable scholars established Arabic schools that awarded certificates that qualified the products of such schools for admission to degree programs in Arab countries such as Egypt, Saudi-Arabia, Syria, Libya, Lebanon, Iraq, Sudan, etc. A further attempt was later made in the 1980s by governments, Muslim philanthropists, and Associations to establish College of Arabic and Islamic Studies. Such institutions were affiliated to one university or the other for the award of Diploma in Arabic and Islamic Studies (Aminu, 2004; Onisabi, Adamu, \& Jami'u, 2007). This has tremendously assisted Nigeria to conduct smooth interaction with Arab countries and other partners at the international levels and tap from the abundance of a lot of economic, cultural, social, political, and educational advantages. The teaching and learning of Arabic in Nigeria have enhanced her nation-building, as it improves diplomatic and transactional relationships with other countries. Thus making the country a part of the global village where investments and businesses are transacted from one place to another with no or little hindrance.

At the secondary school level, Arabic learning has helped student-teachers acquire spoken and written competence in the Arabic language; acquainted them with the socio-political and cultural lives of the speakers of the language, with a view to promoting international understanding; prepared them for the task of teaching the language and enabled them to use Arabic as a medium of instruction (Onisabi, Adamu \& Jami'u, 2007). For human and non-human development, a substantial share of the nation's resources is invested in education. However, it is rather unfortunate that the outcome of students in their graduating examinations in some subjects including Arabic Language after these investments has long been a matter of concern to many well-meaning individuals, institutions, government, and other educational stakeholders (Abdullahi, 2020). The public likewise disparages the falling standard of education as evidenced by the lack of skills and personal integrity of many school leavers (Jimoh, 2007) and there have been public outcries over the persistent poor performance of secondary school students in Arabic Language especially in SSCE examinations (WAEC, 2009; Oloyede, 2012).

WAEC and NECO are part of the examination bodies charged with the responsibilities of conducting the final examination and evaluating final year students in Senior Secondary Schools. These examination bodies are tasked with maintaining a common standard in the development and administration of their various examinations and issuing school certificates so as to provide the qualification for admission into any higher educational institution. Thus, the assemblage of subject examinations which are summative in nature conducted by these bodies is known as the Senior Secondary School Certificate Examination 
Abdullahi \& Oladosu | Relationship Between Students' Learning Outcomes in WAEC and NECO Arabic Language Examinations in North-Central Nigeria

(SSCE) and serves as an end-of-course evaluation for all secondary school graduates. The purpose of these two examination bodies is to ascertain to what degree students in a particular course have achieved the course or educational objectives (Owolabi, 2000).

Despite the fact that the certificates being awarded by WAEC and NECO are said to be comparable, stakeholders in the education sector doubt their equivalence in terms of students' performance as some parents prefer WAEC to NECO for their wards while some are otherwise. This is based on some stakeholders' assertion that students' learning outcome in WAEC is better than in NECO. However, some students only register for NECO believing that they could not pass WAEC. If WAEC and NECO are able to maintain high standards in the development and administration of Senior School Certificate Examinations, then performances in the examination should be good indicators of individuals' standings with respect to any of the tested subject areas (Lawal, 2001). How often, however, is this case? It is possible, for instance, to identify candidates who scored in F9 on the WAEC SSCE and an A1 in the NECO SSCE in the same subject and in the same year, thus leaving observers to wonder if the two SSCEs are in fact parallel. The researcher, therefore, attempted to approach this issue by corresponding students' learning outcomes in senior school WAEC and NECO Arabic Language examinations in North-central Nigeria from 2015 to 2019 academic sessions. The study was hunched that public awareness of the comparability of the WAEC and NECO examination results could point at the direction of hope to the citizens and restore public confidence in all these examinations.

The general purpose of this study was to determine the degree of relationship that exists between students' learning outcomes in senior school WAEC and NECO Arabic Language examinations from 2015 to 2019 in North-central Nigeria. Specifically, the study investigated:

Students' learning outcome in WAEC Arabic Language examination in Northcentral Nigeria from 2015 to 2019 academic sessions; students' learning outcome in NECO Arabic Language examination in North-central Nigeria from 2015 to 2019 academic sessions; the relationship between students' learning outcome in WAEC and NECO Arabic Language examinations in North-central Nigeria; the relationship between students' learning outcome in WAEC and NECO Arabic Language examinations in North-central Nigeria based on academic sessions.

Also, the following research questions were answered: What is students' learning outcome in WAEC Arabic Language examination in North-central Nigeria from 2015 to 2019 academic sessions? What is students' learning outcome in NECO Arabic Language examination in North-central Nigeria from 2015 to 2019 academic sessions? 
Abdullahi \& Oladosu | Relationship Between Students' Learning Outcomes in WAEC and NECO Arabic Language Examinations in North-Central Nigeria

\section{Research Hypotheses}

The following hypotheses were postulated and tested:

Ha1: There is no significant relationship between students' learning outcomes in WAEC and NECO Arabic Language examinations in North-central Nigeria.

Ha2: There is no significant relationship between students' learning outcome in WAEC and NECO Arabic Language examinations in North-central Nigeria based on academic session.

\section{METHODS}

This study was a descriptive study of the correlational type. The population for the study comprised all the senior secondary school students offering Arabic Language in North-central Nigeria. There are six states and the Federal Capital Territory (FCT) in North-central Nigeria and these are Benue, Kogi, Kwara, Nasarawa, Niger, Plateau, and FCT, Abuja. Nine hundred and forty-eight (948) students constituted the sample size for the study using a multistage sampling procedure. At the $1^{\text {st }}$ stage, random sampling technique was used to pick four (4) states. At the $2^{\text {nd }}$ stage, random sampling was also used to proportionately select $25 \%$ of the Local Government Areas in each of the sampled states and thus 5 LGAs out of 21 LGAs in Kogi State; 4 LGAs out of 16 LGAs in Kwara State; 3 LGAs out of 13 LGAs in Nasarawa State; and 6 LGAs out of 25 in Niger State. At the $3^{\text {rd }}$ stage, the purposive sampling technique was used to select schools where students sat for both WAEC and NECO Arabic Language examinations in the sampled areas. Therefore, only the results of candidates that sat for WAEC and NECO Arabic Language examinations were logically selected for the study. Thus, 948 students were collated to have sat for WAEC and NECO Arabic Language examinations.

A researcher-designed proforma was used to collect results in the Arabic Language in the schools sampled. The results covered the period of five (5) years (i.e. 2015 to 2019). Both the results of the SSCE WAEC and NECO Arabic Language were the products of standardised, norm-referenced examinations and thus considered to be valid and reliable. The data collected were analyzed via SPSS version 20 using the descriptive statistics of percentage to answer the research questions. Hypotheses postulated were tested using the Pearson's chisquare at 0.05 alpha level via contingency table while the symmetric measure of Cramer's V was used to determine the degree of relationship between the variables.

\section{RESULTS}

Out of 948 students who sat for both WAEC and NECO Arabic examinations in North-central Nigeria, 791 were males while 157 were females. Also, the result of 
Abdullahi \& Oladosu | Relationship Between Students' Learning Outcomes in WAEC and NECO Arabic Language Examinations in North-Central Nigeria

210, 192, 198, 192, and 156 students in both WAEC and NECO Arabic examinations in 2015, 2016, 2017, 2018, and 2019 academic sessions respectively in North-central Nigeria were obtained and used to answer the research questions and test the hypotheses postulated based on their learning outcomes in WAEC and NECO and academic sessions.

\section{Answering of Research Questions}

Question One: What is the students' learning outcome in the WAEC Arabic Language examination in North-central Nigeria from 2015 to 2019 academic sessions?

Students' learning outcomes (results) in the WAEC Arabic Language examination from 2015 to 2019 were collated and subjected to the percentage analysis. The statistics is presented in Table 1.

Table 1. Students' Learning Outcome in Arabic in the West African Senior

School Certificate Examinations between 2015 and 2019 in North-central Nigeria

\begin{tabular}{|c|c|c|c|c|c|c|c|c|c|}
\hline \multirow{2}{*}{ Years } & \multicolumn{8}{|c|}{ Students' Grades in the WASSCE Arabic } & \multirow{2}{*}{$\begin{array}{c}\text { Total } \\
(\%)\end{array}$} \\
\hline & A1 (\%) & B2 (\%) & B3 (\%) & C4 (\%) & C5(\%) & C6 (\%) & D7 (\%) & F9 (\%) & \\
\hline \multirow[t]{2}{*}{2015} & 50 & 52 & 48 & 38 & 16 & 2 & 4 & 0 & 210 \\
\hline & $(5.3 \%)$ & $(5.5 \%)$ & $(5.1 \%)$ & $(4.0 \%)$ & $(1.7 \%)$ & $(0.2 \%)$ & $(0.4 \%)$ & $(0.0 \%)$ & $(22.2 \%)$ \\
\hline \multirow[t]{2}{*}{2016} & 26 & 50 & 38 & 32 & 28 & 18 & 0 & 0 & 192 \\
\hline & $(2.7 \%)$ & $(5.3 \%)$ & $(4.0 \%)$ & $(3.4 \%)$ & $(2.9 \%)$ & $(1.9 \%)$ & $(0.0 \%)$ & $(0.0 \%)$ & $(20.3 \%)$ \\
\hline \multirow[t]{2}{*}{2017} & 36 & 66 & 36 & 24 & 14 & 18 & 2 & 2 & 198 \\
\hline & $(3.8 \%)$ & $(6.9 \%)$ & (3.8) & $(2.5 \%)$ & $(1.5 \%)$ & $(1.9 \%)$ & $(0.2 \%)$ & $(0.2 \%)$ & $(20.9 \%)$ \\
\hline \multirow[t]{2}{*}{2018} & 36 & 58 & 44 & 22 & 28 & 0 & 4 & 0 & 192 \\
\hline & $(3.8 \%)$ & $(6.1 \%)$ & $(4.6 \%)$ & $(2.3 \%)$ & $(2.9 \%)$ & $(0.0 \%)$ & $(0.4 \%)$ & $(0.0 \%)$ & $(20.3 \%)$ \\
\hline \multirow[t]{2}{*}{2019} & 22 & 52 & 34 & 14 & 22 & 10 & 2 & 0 & 156 \\
\hline & $(2.3 \%)$ & $(5.5 \%)$ & $(3.6 \%)$ & $(1.5 \%)$ & $(2.3 \%)$ & $(1.1 \%)$ & $(0.2 \%)$ & $(0.0 \%)$ & $(16.5 \%)$ \\
\hline \multirow[t]{2}{*}{ Total } & 170 & 278 & 200 & 130 & 108 & 48 & 12 & 2 & 948 \\
\hline & $(\mathbf{1 7 . 9 \% )}$ & $(29.3 \%)$ & (21.1\%) & $(13.7 \%)$ & $(11.4 \%)$ & $(5.1 \%)$ & $(1.3 \%)$ & $(0.2 \%)$ & $(100.0 \%)$ \\
\hline
\end{tabular}

Table 1 shows that out of the 948 students that sat for Arabic in the West African Senior School Certificate Examinations (WASSCE) between 2015 and 2019, only 2 (.2\%) had F9; 12 (1.3\%), D7; 48 (5.1\%) C6; 108 (11.4\%), C5; 130 (13.7\%), C4; 200 (21.1\%), B3; 278 (29.3\%), B2; and 170 (17.9\%) A1. Therefore, 98.5\% of the students that sat for the West African Senior School Certificate Examinations (WASSCE) Arabic Language between 2015 and 2019 passed at a credit level (i.e. C6-A1). 
Abdullahi \& Oladosu | Relationship Between Students' Learning Outcomes in WAEC and NECO Arabic Language Examinations in North-Central Nigeria

Question Two: What is the students' learning outcome in the NECO Arabic Language examination in North-central Nigeria from 2015 to 2019 academic sessions?

Students' learning outcomes (results) in the NECO Arabic Language examination between 2015 and 2019 were collated and subjected to the percentage analysis. The statistics are presented in Table 2.

Table 2. Students' Learning Outcome in Arabic SSCE Conducted by the National Examinations Council in North-central Nigeria between 2015 and 2019 Academic Sessions

\begin{tabular}{|c|c|c|c|c|c|c|c|c|}
\hline \multirow[b]{2}{*}{ Years } & \multicolumn{7}{|c|}{ Students' Grade in the NECO Arabic } & \multirow{2}{*}{$\begin{array}{c}\text { Total } \\
(\%)\end{array}$} \\
\hline & A1 (\%) & B2 (\%) & B3 (\%) & C4 (\%) & C5 (\%) & C6 (\%) & D7 (\%) & \\
\hline \multirow[t]{2}{*}{2015} & 46 & 64 & 38 & 36 & 22 & 4 & 0 & 210 \\
\hline & $(4.85 \%)$ & $(6.75 \%)$ & $(4.01 \%)$ & $(3.80 \%)$ & $(2.32 \%)$ & $(0.4 \%)$ & $(0.0 \%)$ & $(22.2 \%)$ \\
\hline \multirow[t]{2}{*}{2016} & 46 & 58 & 36 & 26 & 18 & 6 & 2 & 192 \\
\hline & $(4.85 \%)$ & $(6.12 \%)$ & $(3.80 \%)$ & $(2.74 \%)$ & $(1.90 \%)$ & $(0.6 \%)$ & $(0.2 \%)$ & $(20.3 \%)$ \\
\hline \multirow[t]{2}{*}{2017} & 70 & 62 & 34 & 18 & 10 & 4 & 0 & 198 \\
\hline & $(7.38 \%)$ & $(6.54 \%)$ & $(3.59 \%)$ & (1.90) & $(105 \%)$ & $(0.4 \%)$ & $(0.0 \%)$ & $(20.9 \%)$ \\
\hline \multirow[t]{2}{*}{2018} & 52 & 54 & 36 & 26 & 12 & 12 & 0 & 192 \\
\hline & $(5.49 \%)$ & $(5.70 \%)$ & $(3.80 \%)$ & $(2.74 \%)$ & $(1.27 \%)$ & $(1.27 \%)$ & $(0.0 \%)$ & $(20.3 \%)$ \\
\hline \multirow[t]{2}{*}{2019} & 33 & 42 & 44 & 29 & 8 & 0 & 0 & 156 \\
\hline & $(3.48 \%)$ & $(4.43 \%)$ & $(4.64 \%)$ & $(3.06 \%)$ & $(0.8 \%)$ & $(0.0 \%)$ & $(0.0 \%)$ & $(16.5 \%)$ \\
\hline \multirow[t]{2}{*}{ Total } & 242 & 280 & 192 & 138 & 68 & 26 & 2 & 948 \\
\hline & $(25.5 \%)$ & $(29.5 \%)$ & $(20.3 \%)$ & $(14.6 \%)$ & $(7.2 \%)$ & $(2.7 \%)$ & $(0.2 \%)$ & $(100.0 \%)$ \\
\hline
\end{tabular}

Table 2 shows that out of the 948 students that sat for Arabic SSCE in the National Examinations Council between 2015 and 2019, 2 (.2\%) students had D7; 26 (2.7\%), C6; 68 (7.2\%), C5; 138 (14.6\%), C4; 192 (20.3\%), B3; 280 (29.5\%), B2; and, $242(25.5 \%)$, A1; This implies that 99.7\% students that sat for the National Examinations Council (NECO) Arabic Language examination between 2015 and 2019 passed at a credit level (i.e. C6 - A1) in the NECO Arabic.

\section{Hypotheses Testing}

Given that the data collected were categorical in nature, hypotheses postulated were tested using the Pearson's chi-square at 0.05 alpha level via contingency table, while the symmetric measure of Cramer's V was used to determine the degree of association between the variables.

Hypothesis One: There is significant relationship between students' learning outcomes in WAEC and NECO Arabic Language examinations in North-central Nigeria. 
Abdullahi \& Oladosu | Relationship Between Students' Learning Outcomes in WAEC and NECO Arabic Language Examinations in North-Central Nigeria

Table 3: Relationship between Students' Performance in WASSCE and NECO SSCE Arabic Language

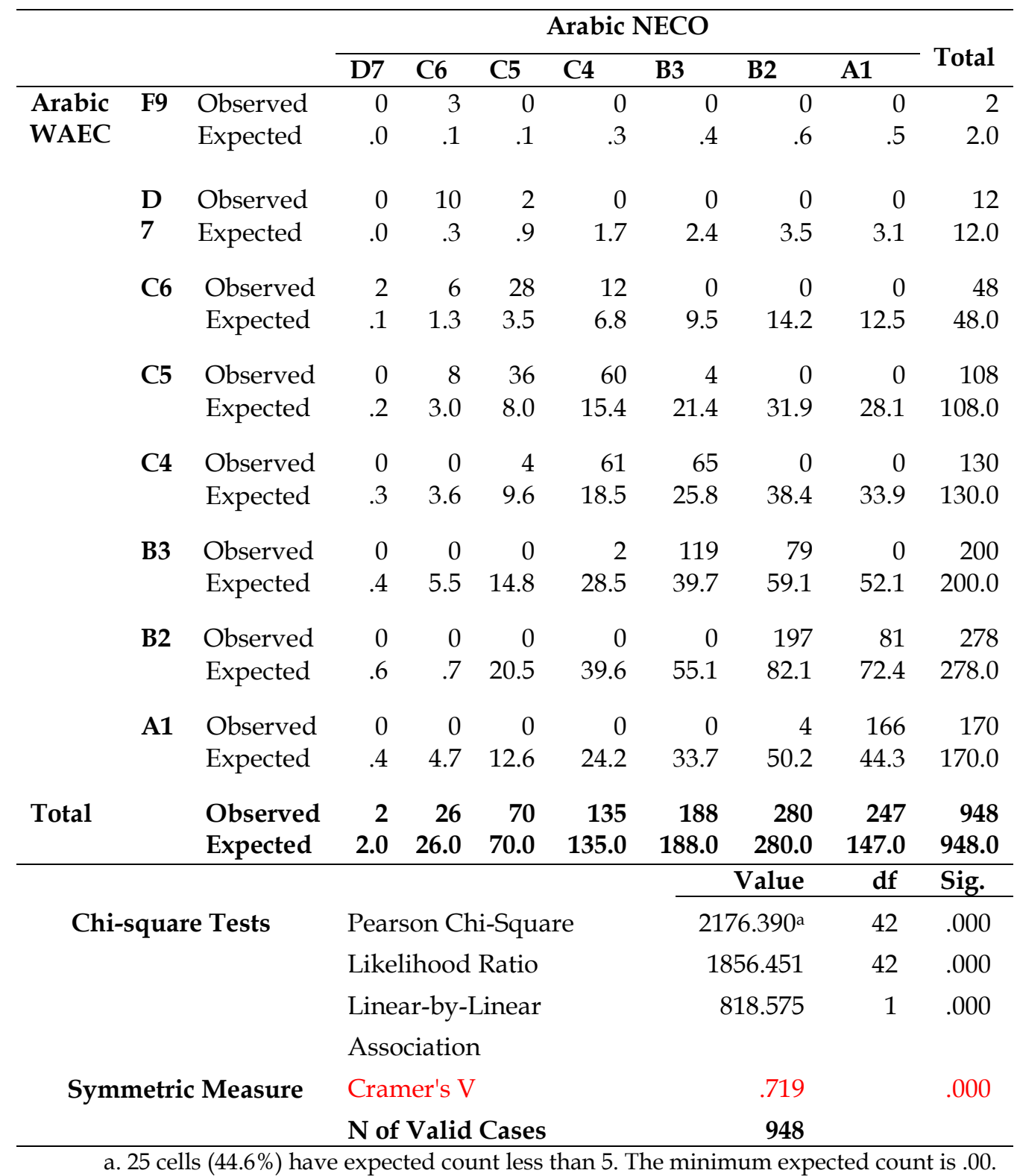

Table 3 shows the statistical relationship of students' learning outcomes in senior school WAEC and NECO Arabic examinations. As revealed in Table 3, the Pearson's Chi-square value 2176.390 with a p-value 0.00 at the degree of freedom 42 was obtained $\left(\chi^{2}(42)=2176.390 ; p<0.05\right)$. Since the $p$-value 0.00 is less than 0.05 alpha level, the alternative hypothesis one is accepted, and thus, there was significant association between students' learning outcomes in WAEC and NECO Arabic examinations in North-central Nigeria.

The degree of relationship between students' learning outcomes in WAEC and NECO Arabic examinations is significantly high and positive as indicated by Cramer's V value 0.719 with p-value 0.00 . This could be observed given the crosstabulation (in Table 3), out of 170 students who had A1 in WAEC Arabic, 166 of 
Abdullahi \& Oladosu | Relationship Between Students' Learning Outcomes in WAEC and NECO Arabic Language Examinations in North-Central Nigeria

them also had A1 in NECO with 4 students having B2 in NECO, and 197 of 298 students who had B2 in WAEC also had B2 in NECO with 81 having A1 in NECO and so on.

Hypothesis Two: There is significant relationship between students' learning outcomes in WAEC and NECO Arabic Language examinations in North-central Nigeria based on academic sessions.

Table 4. Association between Students' Learning Outcome in WAEC and NECO Arabic Language Examinations in North-central Nigeria Based on

Academic Sessions

\begin{tabular}{|c|c|c|c|c|c|c|c|c|c|c|c|c|c|}
\hline \multirow{2}{*}{$\begin{array}{c}\text { Academi } \\
\text { Sessions }\end{array}$} & & \multicolumn{7}{|c|}{ Arabic NECO } & \multirow{2}{*}{ Total } & \multicolumn{3}{|c|}{ Pearson's Chi. } & \multirow{2}{*}{$\begin{array}{c}\text { Cramer's } \\
\text { V }\end{array}$} \\
\hline & & D7 & C6 & C5 & C4 & B3 & B2 & A1 & & $\chi^{2}$ & df & Sig & \\
\hline \multirow{7}{*}{2015} & D7 & & 4 & 0 & 0 & 0 & 0 & 0 & 4 & \multirow{7}{*}{$889.28^{b}$} & \multirow{7}{*}{30} & \multirow{7}{*}{.000} & \multirow{7}{*}{.920} \\
\hline & C6 & & 0 & 2 & 0 & 0 & 0 & 0 & 2 & & & & \\
\hline & C5 & & 0 & 16 & 0 & 0 & 0 & 0 & 16 & & & & \\
\hline & $\mathrm{C} 4$ & & 0 & 4 & 34 & 0 & 0 & 0 & 38 & & & & \\
\hline & B3 & & 0 & 0 & 2 & 38 & 8 & 0 & 48 & & & & \\
\hline & B2 & & 0 & 0 & 0 & 0 & 52 & 0 & 52 & & & & \\
\hline & A1 & & 0 & 0 & 0 & 0 & 4 & 46 & 50 & & & & \\
\hline \multirow{8}{*}{2016} & Total & & 4 & 22 & 36 & 38 & 64 & 46 & 210 & \multirow{8}{*}{$487.27^{\mathrm{c}}$} & \multirow{7}{*}{30} & \multirow{7}{*}{.000} & \multirow{7}{*}{.712} \\
\hline & C6 & 2 & 6 & 10 & 0 & 0 & 0 & 0 & 18 & & & & \\
\hline & $\mathrm{C} 5$ & 0 & 0 & 8 & 20 & 0 & 0 & 0 & 28 & & & & \\
\hline & $\mathrm{C} 4$ & 0 & 0 & 0 & 6 & 26 & 0 & 0 & 32 & & & & \\
\hline & B3 & 0 & 0 & 0 & 0 & 10 & 28 & 0 & 38 & & & & \\
\hline & B2 & 0 & 0 & 0 & 0 & 0 & 30 & 20 & 50 & & & & \\
\hline & A1 & 0 & 0 & 0 & 0 & 0 & 0 & 26 & 26 & & & & \\
\hline & Total & 2 & 6 & 18 & 26 & 36 & 58 & 46 & 192 & & \multirow{9}{*}{35} & \multirow{9}{*}{.000} & \multirow{9}{*}{.817} \\
\hline \multirow{8}{*}{2017} & F9 & & 2 & 0 & 0 & 0 & 0 & 0 & 2 & \multirow{8}{*}{$660.68^{d}$} & & & \\
\hline & D7 & & 2 & 0 & 0 & 0 & 0 & 0 & 2 & & & & \\
\hline & C6 & & 0 & 10 & 8 & 0 & 0 & 0 & 18 & & & & \\
\hline & $\mathrm{C} 5$ & & 0 & 0 & 10 & 4 & 0 & 0 & 14 & & & & \\
\hline & $\mathrm{C} 4$ & & 0 & 0 & 0 & 24 & 0 & 0 & 24 & & & & \\
\hline & B3 & & 0 & 0 & 0 & 6 & 30 & 0 & 36 & & & & \\
\hline & B2 & & 0 & 0 & 0 & 0 & 32 & 34 & 66 & & & & \\
\hline & A1 & & 0 & 0 & 0 & 0 & 0 & 36 & 36 & & & & \\
\hline \multirow{7}{*}{2018} & Total & & 4 & 10 & 18 & 34 & 62 & 70 & 198 & & & & \\
\hline & D7 & & 4 & 0 & 0 & 0 & 0 & 0 & 4 & & & & \\
\hline & $\mathrm{C} 5$ & & 8 & 12 & 8 & 0 & 0 & 0 & 28 & & & & \\
\hline & $\mathrm{C} 4$ & & 0 & 0 & 18 & 4 & 0 & 0 & 22 & $513.49^{\mathrm{e}}$ & 25 & .000 & .731 \\
\hline & B3 & & 0 & 0 & 0 & 32 & 12 & 0 & 44 & & & & \\
\hline & B2 & & 0 & 0 & 0 & 0 & 42 & 16 & 58 & & & & \\
\hline & A1 & & 0 & 0 & 0 & 0 & 0 & 36 & 36 & & & & \\
\hline & Total & & 12 & 12 & 26 & 36 & 54 & 52 & 192 & & & & \\
\hline & D7 & & & 2 & 0 & 0 & 0 & 0 & 2 & & & & \\
\hline & C6 & & & 6 & 4 & 0 & 0 & 0 & 10 & & & & \\
\hline & $\mathrm{C} 5$ & & & 0 & 22 & 0 & 0 & 0 & 22 & $462.99^{f}$ & 24 & .000 & .861 \\
\hline 2019 & $\mathrm{C} 4$ & & & 0 & 3 & 11 & 0 & 0 & 14 & & & & \\
\hline & B3 & & & 0 & 0 & 33 & 1 & 0 & 34 & & & & \\
\hline & B2 & & & 0 & 0 & 0 & 41 & 11 & 52 & & & & \\
\hline & A1 & & & 0 & 0 & 0 & 0 & 22 & 22 & & & & \\
\hline & Total & & & 8 & 29 & 44 & 42 & 33 & 156 & & & & \\
\hline & d Total & 2 & 26 & 70 & 135 & 188 & 280 & 247 & 948 & & & & \\
\hline
\end{tabular}

b. 23 cells $(54.8 \%)$ have expected count less than 5 . The minimum expected count is .04 .

c. 25 cells $(59.5 \%)$ have expected count less than 5 . The minimum expected count is .19 .

d. 34 cells $(70.8 \%)$ have expected count less than 5 . The minimum expected count is .04 .

e. 20 cells $(55.6 \%)$ have expected count less than 5 . The minimum expected count is 25 .

f. 23 cells $(65.7 \%)$ have expected count less than 5 . The minimum expected count is .10 . 
As shown in Table 4, all the p-values (.000) obtained at varying degrees of freedom are significant $(\mathrm{p}<0.05$ alpha level) with high strengths of association between WAEC and NECO Arabic examinations for the respective academic sessions. However, students' learning outcomes in the 2015 WAEC and NECO Arabic examination were highly aligned (.920) followed by students' learning outcomes in 2019, 2017, 2018, and 2016 with their respective values .861, .817, .731 , and .712. Therefore, alternative hypothesis two is accepted.

\section{Discussion of the Findings}

The findings of this study revealed that the learning outcome of students in Arabic in the West African Examination Council was excellent. This could be attributed to students' familiarisation with Arabic studies right from their early stage. The finding aligns with the submission of Ajidagba (2002), Ibrahim (2008), Yusuf (2018) and Jimba(2021), that if students were exposed to Arabic scripts (texts) right from the primary school level, they would be able to read and write both the Qur'an and Hadith correctly in their original Arabic text, at the senior secondary level. This finding is also in line with the submission of Salisu (2015), Saadu (2017), and Yahaya (2018). For instance, Salisu and Abdullahi's (2017) research outcome revealed that students' performance in the Arabic Language was generally good, Saadu (2017) found that the general knowledge of Arabic Language among Arabic undergraduates in the University of Ilorin was relatively high, and Yahaya (2018) study showed that the overall performance of students in WASSCE Arabic language was good. The finding is contrary to Abdullahi and Salisu (2017) who found that students' performance in Arabic Language essay writing was relatively fair in Kwara state.

The findings also showed that students' learning outcome in Arabic in the National Examinations Council (NECO SSCE) in North-central Nigeria was found to be $99.7 \%$, which was also an excellent performance. This finding negated Abdullahi's (2014) finding that students' performance in Arabic was very poor in the 2014 NECO SSC Examination. The improvement in the students' performance in Arabic based on the researcher's informal interaction with the teachers and students could be attributed to the improvement in the teachers' commitment, positive attitude both from parents and students towards the subject, teaching method, and more qualified and experienced teachers teaching the subjects. In addition, this study revealed that a significant association existed between students' learning outcomes in WAEC and NECO Arabic examinations in North-central Nigeria and their degree of association was high and positive. However, on the basis of academic sessions, students' learning outcomes in the 2015 WAEC and NECO Arabic examination were highly aligned followed by students' learning outcomes in 2019, 2017, 2018, and 2016 academic sessions respectively. The finding also corroborated those of Ayodele (2002), Ibrahim (2008), and Yahaya (2018) who reported in their individual studies that there was a statistically significant relationship between students' performance in WASSCE and NECO. This is to say that students who scored high marks in the WAEC 
Abdullahi \& Oladosu | Relationship Between Students' Learning Outcomes in WAEC and NECO Arabic Language Examinations in North-Central Nigeria

were also the set of students that scored comparatively high scores in the NECO. Contrary to this submission, Shittu (2012) found that there was no concurrent validity in the students' performance in WAEC and NECO SSCEs Arabic grades for the years considered. The finding is not consistent with Adeniran (2000) submission that NECO SSC Examinations are inferior to the WAEC SSC Examinations in all standards. It also disagrees with the submission of Olutola (2011) that WAEC SSCE multiple-choice items have more difficult items than NECO SSCE multiple-choice items in all subjects.

\section{CONCLUSION}

With respect to the findings of this study, it could be concluded that students are performing excellently in SSCE Arabic Language and this could not only assist them in Qur'anic and Hadith recitation, understanding, and interpretation but also enable them to imbibe Islamic culture, moral and doctrines in Nigeria. Also, it could be concluded that there exists high degree of association between both WAEC and NECO Arabic examinations regardless of academic sessions. Students who perform better in the WAEC Arabic examination are prone to perform better in the NECO Arabic examination. Given the findings of this study, the following recommendations are proffered. Teachers of Arabic should work harder to sustain their students' performance in the Arabic Language. Arabic teachers should improve on the method of teaching Arabic grammar as a prerequisite for comprehending Arabic literature, rhetoric, prosody, etc. Parents and Arabic teachers should sensitize students on the need to partake in Arabic classes at home and in schools. This practice could encourage students to study Arabic Language and make it their course of study at higher institutions.

\section{REFERENCE}

Abdullahi, A. I. (2014). English language proficiency and teacher factors as correlates of senior school students' achievement in Mathematics in Lagos State. Ilorin Journal of Education, 33, 42-54.

Abdullahi, M. S. \& Salisu, M. (2017). Evaluation of essay writing among senior secondary school Arabic students in Kwara state, Nigeria. Anatolian Journal of Education, 2, 1-7.

Abdullahi, M. S. (2020). Performance in Arabic as a correlate of senior secondary school students' performance in Islamic Studies in North-Central Nigeria. [Doctoral thesis, University of Ilorin]. Nigeria.

Abdullahi, M. S. (2020). Performance in Arabic as a correlate of senior secondary school students' performance in Islamic Studies in North-Central Nigeria. [Doctoral thesis, University of Ilorin]. Nigeria. 
Abdullahi \& Oladosu | Relationship Between Students' Learning Outcomes in WAEC and NECO Arabic Language Examinations in North-Central Nigeria

Adeniran, T. (2000, February 29). NECO certificate valid for varsity admission. The Punch Newspaper of Tuesday, 29.

Adeyemi, K. A. (2016). The trend of Arabic and islamic education in Nigeria: progress and prospects. Open Journal of Modern Linguistics, 6, 197-201. http://dx.doi.org/10.4236/ojml.2016.63020

Ahmad, K. (2009). Leadership and work motivation from the cross-cultural perspective. International Journal of Commerce and Management, 19(1), 72-84. https://doi.org/10.1108/10569210910939681

Ajidagba, U. (2002). Student competence in Arabic language as a predictor of performance in junior secondary school of Islamic Studies. Ilorin Journal of Education, 21, 85-92.

Akyol, A. (2018). Jabir Ibn Hayyan's classification of science and its place in islamic epistemology. Marife Dini Araştırmalar Dergisi, 18(1), 11-22. https://doi.org/10.33420/marife.402802

Aminu, O. (2004). Arabic language in Nigeria: an educational and cultural heritage. In Oguniyi, A. K. T., Barihi, A. and Yusuf, T. O. (Eds) Studies on Arabic acculturation in Nigeria. Part One, Ilorin. Taofiqullahi Publishing House.

Ayodele, O. (2002). Errors of articles, prepositions and conjuctions in the written English of senior secondary school students in Ilorin, Nigeria. [Doctoral thesis, University of Ilorin]. Nigeria.

Hamidin, N. H. (2015). Effective technique of teaching and learning Arabic language in the classroom: A case study in selected national religious secondary schools (SMKA) in Selangor. In The International Conference on Language, Literature, Culture and Education 2015 proceedings. https://icsai.org/procarch/2icllce/2icllce-109.pdf

Ibrahim, A. (2008). Relationship between students' academic performance in Arabic and Islamic studies in the senior school certificate examination in Ilorin, Kwara State, Nigeria. [Doctoral thesis, University of Ilorin]. Nigeria.

Jimba, A. I. (2021). An assessment of Almajiri integrated model school pupils' performance in Qur'anic subjects in Sokoto state, Nigeria. International Journal of Islamic Educational Psychology, 2(1), 1-14. https://doi.org/10.18196/ijiep.v2i1.11400 
Abdullahi \& Oladosu | Relationship Between Students' Learning Outcomes in WAEC and NECO Arabic Language Examinations in North-Central Nigeria

Jimoh, M. I. (2007). Relationship among continuous assessment, WAEC and NECO Geography SSCE results in Ilorin west local government area, Nigeria. [Doctoral thesis, University of Ilorin]. Nigeria.

Khaidir, E., \& Suud, F. M. (2020). Islamic education in forming students' characters at as-shofa Islamic High School, Pekanbaru Riau. International Journal of Islamic Educational Psychology, 1(1), 50-63. https://doi.org/10.18196/ijiep.1101

Lawal, R. A. (2001). Types and uses of tests. Fundamental principles and practice of instruction (pp. 332-353). Department of Curriculum Studies and Educational Technology.

Ogunbanwo, R. A. (2014). Analysis of students' performance in west african senior Certificate Examinations in Boarding and Day Secondary Schools in Kano Metropolis, Nigeria (2005-2011). (Publication no. 6465) [Doctoral thesis, Ahmadu Bello University, Zaria-Nigeria]. Open Access Institutional Repository at Ahmadu Bello University, Zaria-Nigeria.

Oladosu, A. G. A. S. (2003). Arabic and Islamic education in Nigeria. In J.O.O. Abiri and A.A. Jekayinfa (Eds.). Perspectives on the History of Education in Nigeria (pp.198-216). Ilorin: Haytee Press and Publishing.

Onisabi, A. S., Adam, G. A. \& Jami'u A. M. (2007). Arabic education in Nigeria, prospects and challenges. The National conference organised by the school of education, Kaduna State College of Education, Gidan-waga, Kafachan.

Oseni, Z. I. (2004). AI-Ma'dubat al-Adabiyyah li-tullab al-cArabiyyah fi ifriqiya alGharbiyyah: A literary banquet for Arabic students in West Africa. Auchi, Nigeria: Darun-Nur.

Owolabi, H. (2000). Assessment in the classroom. Ilorin: Faculty of Education.

Saadu, M. M. (2017). Influence of A rabic knowledge on learning Islamic studies among undergraduates of University of Ilorin, Nigeria. B.A. (Ed.) Project submitted to the Institute of Education, Faculty of Education, University of Ilorin, Ilorin, Nigeria.

Salisu, M. \& Abdullahi, M. S. (2017). Pronunciation difficulties among upperbasic Hausa-speaking students of Arabic in Kano State. The Springboard Journal, 9(1), 15-26.

Shittu, H. (2012). Concurrent validity of WAEC and NECO senior certificate Arabic examination in Kebbi State. [Doctoral thesis, University of Ilorin]. Nigeria. 
Abdullahi \& Oladosu | Relationship Between Students' Learning Outcomes in WAEC and NECO Arabic Language Examinations in North-Central Nigeria

Sirajudeen, A. A. (2003). Colonial impact on the issue of Arabic in Nigeria. Anyigba Journal of Arts and Humanities, 2(2), 1-8.

Wekke, I. S. (2015). Arabic teaching and learning: A model from Indonesian Muslim minority. Procedia-Social and Behavioral Sciences, 191, 286-290. https://doi.org/10.1016/j.sbspro.2015.04.236

Wekke, I. S., Ernawati, \& Hudaya, U. (2016). Aspects of Arabic teaching and learning in elementary madrasah on minority muslim Indonesia. In The International Conference Arabic Language Education and Literature and Islamic Values Between Expectation and Realization Bandung 2016 proceedings. https://osf.io/ua63d/download

Yahaya, T. (2018). Relationship between students' performance in Arabic and Islamic studies in WAEC SSC examinations (2011-2015) in Kwara State, Nigeria. [Doctoral thesis, University of Ilorin]. Nigeria.

Yusuf, A. W. (2018). Availability and use of instructional materials for teaching Arabic in senior secondary schools in Kwara State, Nigeria. Journal of Teaching and Teacher Education, 6(1), 59-64.

Yusuf, M., \& Wekke, I. S. (2015). Active learning on teaching Arabic for special purpose in Indonesian Pesantren. Procedia-Social and Behavioral Sciences, 191, 137-141. https:// doi.org/10.1016/j.sbspro.2015.04.245 